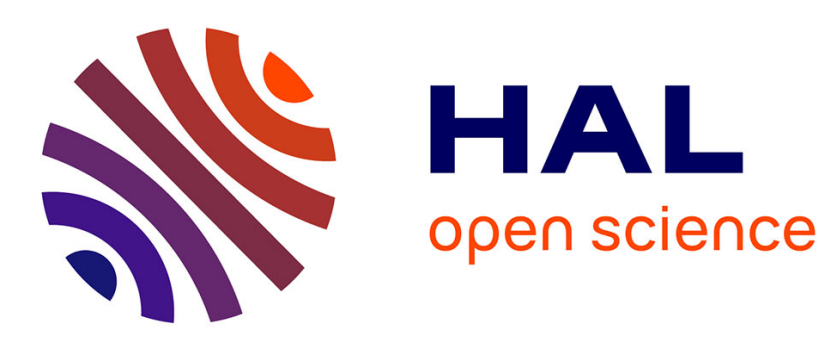

\title{
A modelling framework for model based risk analysis
}

Jean-Marie Flaus

\section{To cite this version:}

Jean-Marie Flaus. A modelling framework for model based risk analysis. Safety and Reliability for Managing Risk ESREL'11, 2011, Troyes, France, France. 1 p. hal-00952772

\section{HAL Id: hal-00952772 \\ https://hal.science/hal-00952772}

Submitted on 27 Feb 2014

HAL is a multi-disciplinary open access archive for the deposit and dissemination of scientific research documents, whether they are published or not. The documents may come from teaching and research institutions in France or abroad, or from public or private research centers.
L'archive ouverte pluridisciplinaire HAL, est destinée au dépôt et à la diffusion de documents scientifiques de niveau recherche, publiés ou non, émanant des établissements d'enseignement et de recherche français ou étrangers, des laboratoires publics ou privés. 


\title{
A Modelling Framework for Model Based Risk Analysis
}

\author{
Jean-Marie Flaus \\ jean-marie.flaus@grenoble-inp.fr
}

\begin{abstract}
G-SCOP, Laboratoire des Sciences pour la Conception, l'Optimisation et la Production de Grenoble - UMR5272 46, avenue Félix Viallet - 38031 Grenoble Cedex 1, France
\end{abstract}

Traditionally, risk analysis projects use a document based approach: the description of the system and the result of the analysis are expressed in a textual way or in drawings without an explicit semantics. The consistency and the relationships between documents are difficult to assess and it is rather difficult to extract and manipulate needed information for validation or for another purposes, or to capitalize knowledge.

An approach to overcome these limitations is to use a model based approach for risk analysis. This would allow to represent knowledge in a consistent manner, easy to manipulate and to transform

In this work, we present an approach for model based risk analysis, which can be used with any classical methods such as PHA, HAZOP and FMEA.

The idea is to describe the physical system according to three views:

- the first one describes the structure (physical and functional),

- a second one, optional, with information about the behaviour when this is useful,

- and a third one to express the risk analysis result.

The first view, called SysFis, has three kinds of models blocks: systems, functions and resources: a system may be seen as an entity whose goal is defined by a set of functions which requires and/or consumes physical elements, called resources, to produce and/or acts on others resources.

From a system engineering model point of view, the SysFis modelling view uses function and resources that may be seen as two types of components used to describe two complementary aspects of the system: the physical and functional ones.

This view may be optionally completed by the behaviour view, called SimFis, which allows for the addition of variables and constraints in order to provide more details about some parts of the system. As the goal is to avoid modelling overhead to the risk analyst, this model view is optional and may be partial.

The result of the analysis is then expressed using the last view, called DysFis, which allows the representation of the abnormal behaviour of the system at a level of abstraction which is relevant for risk analysis. This view is based on model blocks defining abnormal events and rules for connecting them. A small set of abnormal events types has been defined. This model is related to the structurofunctional model and to the behaviour model. It allows to automatically generate tables for various risk analysis and various representations such as fault tree, consequence tree, bow tie diagram and to compute probability or severity.

A software tool, XRisk, has been developed to implement and to test this modelling approach. This tool allows to perform model based risk analysis and is able to generate, from a common representation, various risk analysis views such as PHA, FMEA, HAZOP, or MOSAR. 